Volume 3

Issue 2 -- Infectious Disease

Article 1

$4-22-2016$

\title{
Blastomyces: Why Be Dimorphic?
}

Dennis J. Baumgardner

Follow this and additional works at: https://aah.org/jpcrr

Part of the Bacterial Infections and Mycoses Commons, Fungi Commons, Infectious Disease Commons, Other Ecology and Evolutionary Biology Commons, and the Pathogenic Microbiology

Commons

\section{Recommended Citation}

Baumgardner DJ. Blastomyces: Why be dimorphic? J Patient Cent Res Rev. 2016;3:61-63. doi: 10.17294/ 2330-0698.1256

Published quarterly by Midwest-based health system Advocate Aurora Health and indexed in PubMed Central, the Journal of Patient-Centered Research and Reviews (JPCRR) is an open access, peer-reviewed medical journal focused on disseminating scholarly works devoted to improving patient-centered care practices, health outcomes, and the patient experience. 


\title{
Blastomyces: Why Be Dimorphic?
}

\author{
Dennis J. Baumgardner, MD | Message from the Editor-in-Chief \\ Department of Family Medicine, Aurora University of Wisconsin Medical Group, Aurora Health Care, Milwaukee, WI
}

Greetings and welcome to our special issue dedicated to the study of infectious diseases. This subject is especially near and dear to my heart since, a long time ago in a galaxy far far away, I studied microbiology prior to becoming a physician — and, shockingly, I continue to put this undergraduate degree to use some 40 years later. You may notice two of the articles in this issue wholly or partly deal with the environmentally acquired fungal disease blastomycosis. ${ }^{1,2}$ While not claiming to be an expert, this disease and the organisms involved have kept me fascinated and engaged for more than 25 years.

Blastomycosis was first described in the late $1800 \mathrm{~s}$, with a high proportion of recognized cases confined to the skin. ${ }^{3}$ We now recognize that almost all cases occur following inhalation of conidia (spores) from the environmental source into the lungs. The pulmonary infection that may follow is often asymptomatic, but can range from mild to severe to life-threatening. The fungus may disseminate from the lungs and cause disease in a variety of organs and tissues, including the skin. ${ }^{4}$ The etiologic agents of blastomycosis are now considered members of one of two species, Blastomyces dermatitidis or Blastomyces gilchristii. ${ }^{5}$ But at least two central mysteries pertaining to Blastomyces persist.

One of the mysteries, as discussed in this issue by Huber et al., is that the particular environmental niche of Blastomyces, if there is a specific one, is still being elucidated. ${ }^{1}$ These organisms are dimorphic microscopic fungi. What does that mean? Simply put, they are microbial "switch-hitters" that grow as a mold at normal environmental temperatures, then undergo

Correspondence: Dennis J. Baumgardner, MD, Aurora Sinai Medical Center, 1020 N. 12th Street, \#4180, Milwaukee, WI, 53233, T: 414-219-5191, F: 414-219-3116, Email: dennis.baumgardner@aurora.org a complex phase transition and grow as a broad-based, budding yeast at body temperature (and under certain other conditions). ${ }^{4,6-8}$

The second mystery yet to be solved is exactly why these organisms evolved this dimorphic ability and devote so much genetic and cellular

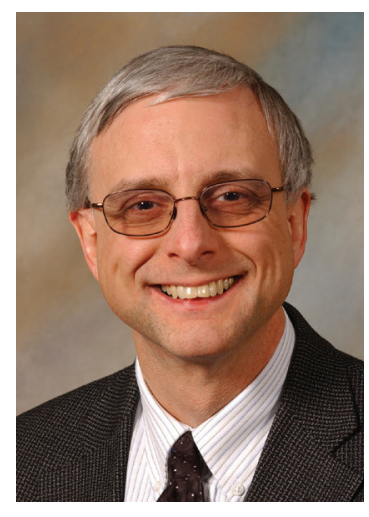
machinery to the phase transition. Clearly, a transition to yeast at body temperature allows the fungus to successfully infect and propagate within a mammal - outside of the laboratory, this occurs predominantly in dogs, humans and an occasional domesticated cat. The resultant yeast cell is too large to be ingested by polymorphonuclear neutrophils (PMNs), unlike the smaller infectious conidia particles (spores). The yeast is also less readily killed by PMNs and peripheral blood monocytes. ${ }^{6}$ Recent experiments in mice suggest that ingestion of spores by alveolar macrophages, conversion of the spores to yeast and a transient intracellular residence in these macrophages may be important for early successful pulmonary infection. ${ }^{9}$

But what does successful infection of the known susceptible humans and animals do for the long-term success of Blastomyces as a competitive environmental species? Is there any other possible reason for this (predominantly) thermal dimorphism? Such knowledge gaps beg for speculation among scientists (and much of the remainder of this commentary is just that).

At least in the modern era, humans and domesticated mammals are considered dead-end hosts for Blastomyces. ${ }^{3}$ There is virtually no person-to-person or animal-to-person spread. While genomic analysis suggests that another dimorphic fungus, Coccidioides (endemic to southwest North America and portions of Central and South America), resides in mammalian 
host carcasses within soil rather than the soil itself, ${ }^{10}$ the contribution of mammalian host carcasses in the natural environment to propagation of Blastomyces is unknown. No significant animal natural host or vector has yet been identified. ${ }^{11}$ This differs from a related dimorphic fungus, Paracoccidioides brasiliensis, which has been shown to have a natural mammalian host, the armadillo, that may have afforded a long coexistence with the fungus. ${ }^{12}$ Bagagli et al. hypothesized that parasitism (yeast-form colonization/ infection of a warm-blooded animal) helps the Paracoccidioides fungus "find shelter, food and opportunities for multiplication and dispersal," thereby increasing the opportunity for sexual reproduction to minimize genetic weakness. ${ }^{12}$

It is certainly conceivable that Blastomyces could be spread to the natural environment from a person or animal with fulminating pulmonary blastomycosis via expectorated sputum or saliva containing significant yeast forms of the organism. ${ }^{13}$ Saliva, in fact, may help protect yeast-phase Blastomyces from lysis by bacteria on natural substances. ${ }^{14}$ Blastomyces also has been identified in mammalian stool, including human, ${ }^{15}$ $\operatorname{dog}^{16}$ and, via experimental oral inoculation, bat. ${ }^{17}$ Neither Blastomyces nor a related dimorphic fungus, Histoplasma capsulatum, have been isolated from the cloaca of birds; however, the latter has been strongly associated with bird guano. ${ }^{18}$ Could temporary or more permanent colonization of the gastrointestinal tract of a known host or a previously unrecognized associated animal be common enough to qualify as important for the dispersal of Blastomyces? The transient passage of fungal forms in feces of those animals with fulminating pulmonary infection would presumably be rare, but perhaps frequent enough for effective dispersal, especially in centuries prior to modern sanitation (Blastomyces and relatives likely date back several million years ${ }^{12}$ ). Could inadvertent swallowing of mold forms of the fungus and colonic passage of mold or yeast forms by animals that feed or peck among soil offer a more common form of dispersal? Blastomyces strains have been shown to grow in vitro when exposed to ammonia levels up to $42-62 \mathrm{mmol} / 1$ in the mold form ${ }^{19}$ and at least $21 \mathrm{mmol} / \mathrm{l}$ in the yeast form (Dennis Baumgardner, unpublished observations). This may be critical, given elevated ammonia concentrations in excreta of birds, ${ }^{20}$ the large intestine of rodents ${ }^{21}$ and human colons in which levels up to $60-70 \mathrm{mmol} / 1$ may be transiently reached. ${ }^{22}$

As we have previously discussed, ${ }^{23}$ at least one Blastomyces strain (ER-3/ATCC MYA 2586) appears to be nonpathogenic in the laboratory (Bruce Klein, personal communication; and as reported by the Broad Institute $^{24}$ ). However, this strain readily converts to the yeast form at $37^{\circ} \mathrm{C}$ on standard media and, to some extent, at room temperature under certain nutritional conditions. $^{8}$ If there are indeed strains that are inherently nonpathogenic in the environment, it makes the mystery even more intriguing - for example, the purpose could be to colonize (if even transiently), but not infect, mammalian surfaces or the gastrointestinal tract for purposes of dispersal. This possibility was investigated in two groups of animals that yielded negative results. Cultures of the intestinal tracts of 60 shrews and 5 small rodents as well as rectal cultures from several beavers failed to grow Blastomyces. ${ }^{11,25}$ Perhaps thermal dimorphism was critical millions of years ago when warm water environments were frequently encountered and the yeast form afforded some sort of advantage over conidia for water dispersion. We simply do not know.

How then did strains of Blastomyces become pathogenic for animals in the first place? As proposed by Casadevall and colleagues ${ }^{26-28}$ and reiterated by Bagagli et al., ${ }^{12}$ virulence factors of soil-dwelling fungi may have evolved to ward off destruction by nematodes or amoebae, and may have already been in place to survive in mammalian hosts once appropriate mammals evolved. Whereas most of these organisms are restricted from infection by the higher mammalian body temperature, ${ }^{28}$ not so when it comes to dimorphic fungi.

All things considered, it seems plausible that Blastomyces evolved thermal dimorphism for a necessary, but more benign, purpose than infecting and potentially killing us or our companion animals.

Finally, it is no secret we at the Journal of PatientCentered Research and Reviews pride ourselves on publishing patient-based content. Heck, it's right there in our name. So you may be wondering what possible benefit this intellectual discourse adds to the care of the 
patient. As one who has spoken to scores of patients with blastomycosis and their family members, I will testify that people want to know "where this disease comes from," including details of why it lives in a certain environment and how it gets into people. Perhaps this editorial will inform these discussions. Ultimately, further research into the whys and hows of blastomycosis pathogenesis may lead to improved treatment.

Besides, isn't science fun?

\section{References}

1. Huber ME, Baumgardner DJ, Kram JJF, Lemke MA. Geodemographic features of human blastomycosis in eastern Wisconsin. J Patient Cent Res Rev. 2016;3:90-8.

2. Baumgardner DJ. Disease-causing fungi in homes and yards in the Midwestern United States. J Patient Cent Res Rev. 2016;3:99-110.

3. Brown EM, McTaggart LR, Zhang SX, Low DE, Stevens DA, Richardson SE. Phylogenetic analysis reveals a cryptic species Blastomyces gilchristii, sp. nov. within the human pathogenic fungus Blastomyces dermatitidis. PLoS One. 2013;8(3):e59237. CrossRef

4. Rippon JW. Blastomycosis. In: Medical Mycology: The Pathogenic Fungi and the Pathogenic Actinomycetes, Third Edition. Philadelphia: WB Saunders, 1988, pp. 474-505.

5. Bradsher RW. Blastomycosis. In: Bennett JE, Dolin R, Blaser MJ (eds). Mandell, Douglas, and Bennett's Principles and Practice of Infectious Diseases, Eighth Edition. Philadelphia: Saunders Elsevier, 2015, pp. 2963-73.e2.

6. Klein BS, Tebbets B. Dimorphism and virulence in fungi. Curr Opin Microbiol. 2007;10:314-9. CrossRef

7. Gauthier GM, Sullivan TD, Gallardo SS, et al. SREB, a GATA transcription factor that directs disparate fates in Blastomyces dermatitidis including morphogenesis and siderophore biosynthesis. PLoS Pathog. 2010;6(4):e1000846. CrossRef

8. Baumgardner DJ, Laundre B. Studies on the molecular ecology of Blastomyces dermatitidis. Mycopathologia. 2001;152:51-8. CrossRef

9. Sterkel AK, Mettelman R, Wüthrich M, Klein BS. The unappreciated intracellular lifestyle of Blastomyces dermatitidis. J Immunol. 2015;194:1796-805. CrossRef

10. Sharpton TJ, Stajich JE, Rounsley SD, et al. Comparative genomic analyses of the human fungal pathogens Coccidioides and their relatives. Genome Res. 2009;19:1722-31. CrossRef

11. Baumgardner DJ, Summerbell R, Krajden S, et al. Attempted isolation of Blastomyces dermatitidis from native shrews in northern Wisconsin, USA. Med Mycol. 2005;43:413-6. CrossRef

12. Bagagli E, Bosco SM, Theodoro RC, Franco M. Phylogenetic and evolutionary aspects of Paracoccidioides brasiliensis reveal a long coexistence with animal hosts that explain several biological features of the pathogen. Infect Genet Evol. 2006;6:344-51. CrossRef
13. McDonough ES, VanProoien R, Lewis AL. Lysis of Blastomyces dermatitidis yeast-phase cells in natural soil. Am J Epidemiol. 1965;81:86-94.

14. McDonough ES, Hierl DJ. Survival and growth of Ajellomyces (Blastomyces) dermatitidis on oak leaves coated with saliva. Mycopathologia. 1987;99:57-60. CrossRef

15. Witorsch P, Utz JP. North American blastomycosis: a study of 40 patients. Medicine (Baltimore). 1968;47:169-200.

16. Baumgardner DJ, Paretsky DP. Identification of Blastomyces dermatitidis in the stool of a dog with acute pulmonary blastomycosis. J Med Vet Mycol. 1997;35:419-21. CrossRef

17. Chaturvedi VP, Randhawa HS, Kini S, Khan ZU. Survival of Blastomyces dermatitis in the gastrointestinal tract of an orally infected insectivorous bat, Rhinopoma hardwickei hardwickei Gray. J Med Vet Mycol. 1986;24:349-52. CrossRef

18. Deepe GS Jr. Histoplasma capsulatum (Histoplasmosis). In: Bennett JE, Dolin R, Blaser MJ (eds). Mandell, Douglas, and Bennett's Principles and Practice of Infectious Diseases, Eighth Edition. Philadelphia: Saunders Elsevier, 2015, pp. 2949-62.e1.

19. Baumgardner DJ. Microecology of Blastomyces dermatitidis: the ammonia hypothesis. Med Mycol. 2009;47:745-52.

20. Roxburgh L, Pinshow B. Ammonotely in a passerine nectarivore: the influence of renal and post-renal modification on nitrogenous waste product excretion. $J$ Exp Biol. 2002;205:1735-45.

21. Kim KI, Lee WS, Benevenga NJ. Feeding diets containing high levels of milk products or cellulose decrease urease activity and ammonia production in rat intestine. $J$ Nutr. 1998;128:1186-91.

22. Cherbuy C, Blottiere H, Duee PH. Gut microflora and the colonic epithelium. In: Rambaud JC, Buts JP, Corthier G, Flourie B. Gut Microflora. Paris: John Libbey Eurotext, 2006, pp. 107-30.

23. Baumgardner DJ, Bernhard KA, Egan G. Pulmonary blastomycosis in Vilas County, Wisconsin: weather, exposures and symptoms. J Patient Cent Res Rev. 2015;2:25-33. CrossRef

24. Broad Institute. Dimorphic fungal genomes. http:// www.broadinstitute.org/scientific-community/science/ projects/fungal-genome-initiative/dimorphic-fungalgenomes $\#<\mathrm{i}>$ Blasromyces_dermatitidis,/i._ER-3. Accessed January 29, 2016.

25. Gaus DP, Baumgardner DJ, Paretsky DP. Attempted isolation of Blastomyces dermatitidis from rectal cultures of beaver (Castor canadensis) from north central Wisconsin. Wild Environ Med. 1996;7:192. CrossRef

26. Casadevall A, Steenbergen JN, Nosanchuk JD. 'Ready made' virulence and 'dual use' virulence factors in pathogenic environmental fungi - the Cryptococcus neoformans paradigm. Curr Opin Microbiol. 2003;6:332-7. CrossRef

27. Casadevall A. Fungal virulence, vertebrate endothermy, and dinosaur extinction: is there a connection? Fungal Genet Biol. 2005;42:98-106. CrossRef

28. Robert VA, Casadevall A. Vertebrate endothermy restricts most fungi as potential pathogens. J Infect Dis. 2009;200:1623-6. $\underline{\text { CrossRef }}$

(C) 2016 Aurora Health Care, Inc. 